Jurnal The Messenger, Vol. 11, No. 1A, Special Issue on the School of Multimedia Technology and Communication Postgraduate Symposium, pp. 81-93

P-ISSN: 2086-1559, E-ISSN: 2527-2810

DOI: $10.26623 /$ themessenger.v11i1A.818

\title{
Determinants of Attitudes Towards Web Advertising: An Evidence from Malaysia
}

\section{Penentu Sikap Terhadap Web Advertising: Sebuah Bukti dari Malaysia}

\author{
Nur Syuhada Rahimi ${ }^{1}$, Bahtiar Mohamad ${ }^{1}$, Talhat Alhaiou ${ }^{2}$, Syed Hassan Raza ${ }^{1,3}$ \\ ${ }^{1}$ School of Multimedia Technology and Communication, Universiti Utara Malaysia, \\ Sintok, Kedah, Malaysia \\ ${ }^{2}$ College of Business Administration (CBA), King Saud University, Riyadh 12372, \\ Saudi Arabia \\ ${ }^{3}$ Department of Communication Studies, Bahauddin Zakariya University, Bosan Road, \\ Multan, Punjab, Pakistan \\ *Corresponding author, e-mail: mbahtiar@uum.edu.my
}

\begin{abstract}
The purpose of this study is to examine the factors which influence of the consumer's Attitudes Towards Web Advertisement (ATWA). Drawing conceptual framework from Elaboration Likelihood Model (ELM), the influence of the six independent variables have been analyzed in this study, including informativeness, entertainment, credibility, economic value, interactivity, and materialism. The data has been obtained from 384 Honda users by using online questionnaires. Results of multiple regression analysis have revealed that all six factors influenced the attitude towards Honda web advertising. However, it has been revealed that the informativeness is a most important predictor of the ATWA. This study has shown that Elaboration Likelihood Model is interrelated with the determinants of consumer's attitudes towards Honda web advertisement and offered managerial implication.
\end{abstract}

Keywords: Web Advertisement, Attitude, Malaysia, Elaboration Likelihood Model.

\begin{abstract}
Abstrak
Tujuan dari penelitian ini adalah untuk menguji faktor-faktor yang mempengaruhi sikap konsumen terhadap iklan web (ATWA). Mendeskripsikan kerangka konseptual dari Elaboration Likelihood Model (ELM), pengaruh enam variabel independen telah dianalisis dalam penelitian ini, termasuk keinformatifan, hiburan, kredibilitas, nilai ekonomi, interaktivitas, dan materialisme. Data telah diperoleh dari 384 pengguna Honda dengan menggunakan kuesioner online. Hasil analisis regresi berganda telah mengungkapkan bahwa keenam faktor tersebut mempengaruhi sikap terhadap iklan web Honda. Namun, telah terungkap bahwa keinformatifan merupakan prediktor terpenting dari ATWA. Penelitian ini menunjukkan bahwa Elaboration Likelihood Model (ELM) terkait dengan faktor penentu sikap konsumen terhadap iklan web Honda dan menawarkan implikasi manajerial.
\end{abstract}

Kata Kunci: Iklan Web, Sikap, Malaysia, Elaboration Likelihood Model.

\section{Introduction}

Advertising has been extensively used as a marketing communication tool and defined the techniques used by the company to bring products (Goldsmith \& Lafferty, 2002), services (Yang, Peterson, \& Huang, 2001) and persuading the consumer to respond in a certain way (Raza, Hasnain, \& Khan, 2018) In this modern era, the emergence of the Internet has helped advertisers to practice more interactive methods.

Article History: Received April 21, 2018; Revised May 09, 2019; Accepted May 23, 2019; Published June 02, 2019 
To this end, advertising practices also have been changed rapidly and adopted new interactive technologies and techniques (Wang \& Sun, 2010).

The emergence of Internet Advertising has greatly benefited the advertiser and as well as the consumer. For instance, (Boudreau \& Watson, 2006) stated that the Internet has had a reflective influence on strategic rational since its ability to change organizational structures and cost patterns alter communication with consumers. In this way, use of Internet has helped the advertising industry in various aspects. Apart of it, scholars have identified possible recompenses to web-based advertising that customers may observe including the capability of giving more information to customers via easy click-through (Wang \& Sun, 2010), the handiness of more information in general (Bleier \& Eisenbeiss, 2015), the ability to act on what interests the customers instantly, customer confidentiality (Stephen, 2016), and more fascinating ads (Goldsmith \& Lafferty, 2002)

Among the ways to advertise products or services is using web advertising (Raza, Bakar, \& Mohamad, 2018). Web advertising or web-advertisement consists of impersonal commercial content paid by sponsors, designed for audiences, delivered by video, print, and audio and make it more interactive and user-friendly (Aziz \& Ariffin, 2010). Usually, when advertisements first appeared on the Web, there were banner ads that ran across the top or bottom of a Web page. Basically, through the Web, consumers can gather pricing information, participate in product design, explore promotions, consummate sales, arrange delivery and receive post-purchase support (Bleier \& Eisenbeiss, 2015; Kerr, Schultz, Kitchen, Mulhern, \& Beede, 2015). Web advertising also could be perceived as promoting lifestyles embodied by types of products and brands advertised online (Pollay \& Mittal, 1993).

In this study, the focus is given to the influential factors of consumer's attitudes towards web advertising (ATWA) via Honda website. In this context, attitude can be defined as predispositions to respond in a way towards a specified class of objects (Saadeghvaziri \& Seyedjavadain, 2011). Other scholars have elaborated that attitude as an individual personal evaluation (Wang \& Sun, 2010) emotional feeling attached (Jung, Shim, Jin, \& Khang, 2016), cultural influence (Raza, Hasnain, et al., 2018) and action tendency toward some objects or ideas. Here, the results of previous studies found the attitude towards the myriad web advertising favorable or unfavorable manner to a particular advertising stimulus during a particular exposure occasion (Lutz, 1985). At the same time, Saeed said web attitude towards advertising focuses on the cognitive, affective and behavioural (Saeed et al., 2013). However, some of the researcher divided into several main foci as informativeness, entertainment value, materialism and economy value (Aziz \& Ariffin, 2010; Ling, Piew, \& Chai, 2010)

Therefore, Honda Malaysia has been chosen as a part of the context in this study. In line with Honda Malaysia strongly rides on its slogan 'The Power of Dreams', it indicates the ever changing and rising requirements of the future. A future with improved technology, along with the improved value (Honda, 2014). Honda is the only global corporation that produces a variety of equipment such as motorbikes, vehicles, airliners, marine, and power products, Honda is thus, the world's major engine maker, manufacturing more than 15.2 million products yearly (Andersen \& Zaelke, 2003). For that reason, many factors influence web of attitudes towards advertising that are likely to be seen in those who never visit the Honda website.

On top of that, the main objective of this study is to investigate the influencing factors of attitudes towards web advertising via Honda website. The study also shows

Jurnal The Messenger, Vol. 11, No. 1A, Special Issue on the School of Multimedia Technology and Communication Postgraduate Symposium, pp. 81-93 
that the website stimulates the mind and generate action in line with their thinking. Consequently, the website itself should be good at playing a role in making it more interactive and user-friendly and able to change one's mind about a product or brand. For that reason, this study considers interactive persuasive medium (i.e., Honda website) to understand that how consumers perceive the persuasive content shared online as the act of convincing consumers to think, feel or do what they want. In this way, the study also responds to call made by (Ham, 2017) that how consumers cope with technology-driven persuasion tactics in the Malaysian context.

Literature Review: Conceptual Framework

Based on past research, web advertisement can be defined as a way of advertising that using the Internet and able to provide convenience to the potential consumer's. At the same time, the content of the website itself provides all the information about the products or services with interactive interface. Consumer's also able to access the relevant website anytime and anywhere. On top of that, it gives the opportunity to the marketers to target their customer customized. It is also very important in the context to build brand awareness and brand loyalty among consumers (Saeed et al., 2013)

According to (Korgaonkar \& Wolin, 2002) not surprisingly by the presence of these web advertisement, many companies are turning to the Web to advertise their products or services. Consumers have more control over the web with targeted advertising exposure or in other words the freedom in which they can select how much commercial content they wish to view when they want to view it, and if they want to view it at all. Throughout the site, consumers can gather pricing information, participate in product design, explore promotions, consummate sales, arrange delivery, and receive post-purchase support (Kerr et al., 2015; Korgaonkar \& Wolin, 2002). In other words, web advertising can give great impact to their viewer.

Other than that, (Saeed et al., 2013) stated that another research was done in Malaysia revealed that consumers of Malaysia have a negative and positive attitude towards internet and web advertising. In terms of operational influence factors of attitude towards Honda web advertising via the website, some researchers stated that the influence of factors of attitude usually depends on six main factors including informativeness, entertainment value, credibility, interactivity, economy value, and materialism. Here, we can see that all these independent variables have a high potential in the context influence factors of consumer's attitude towards Honda web advertising via the website (Ling et al., 2010).

This study has applied one of the persuasion models which is The Elaboration Likelihood Model (ELM) to identify the influence factors of consumer's attitude towards advertising via Honda's website. The ELM is a model of how attitudes are formed or changed (Petty \& Cacioppo, 1986). A final way in which variables can affect attitudes is by influencing the confidence people have in their thoughts. Thought confidence is important because it determines whether people will rely on the thoughts they have generated to form attitudes (Petty, Briñol, \& Tormala, 2002). Figure 1 shows the conceptual framework between the independent variables and the dependent variable. 


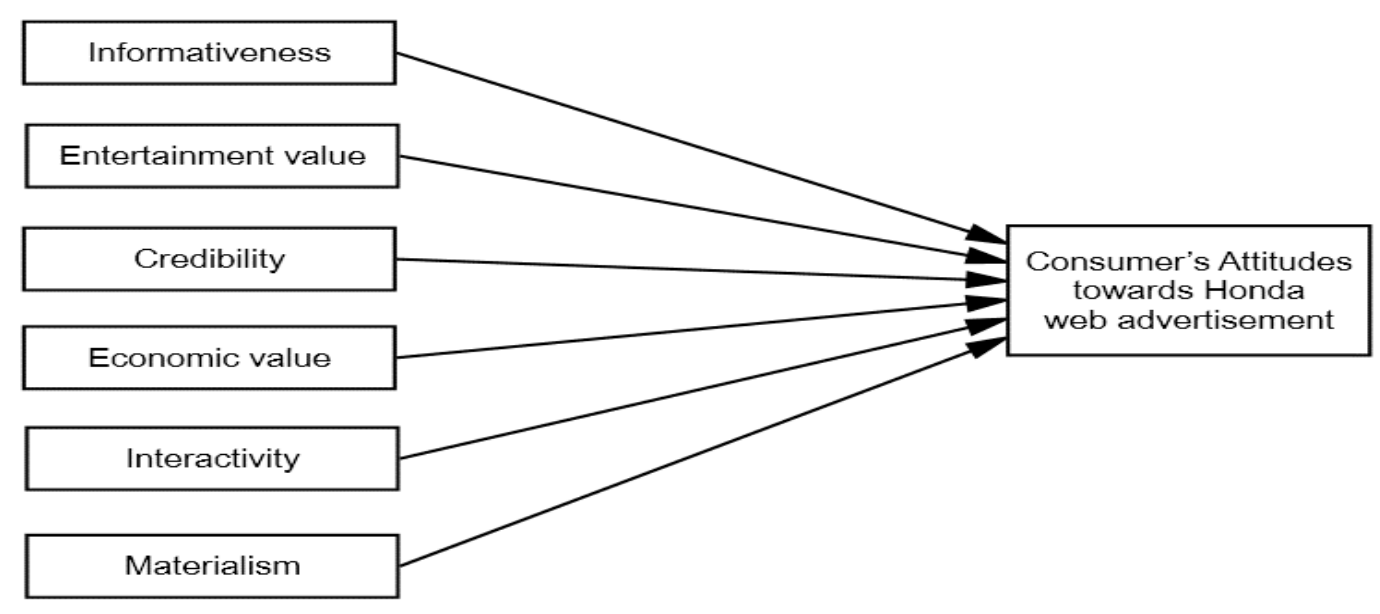

Figure 1. Conceptual Framework Review

Hypotheses Development: Informativeness and Consumer's Attitudes Towards Honda Web Advertisement

Providing information products or services are one of the main reasons for web advertisement exist. Informativeness includes brand in terms of features, convenience source, keep up to date, valuable source, and pleasure in thinking and assist the consumer to decide (Aziz \& Ariffin, 2010). It's particularly important in views their attitude towards the certain website and see the extent to which advertising give effect to them. In addition, (Schlosser, Shavitt, \& Kanfer, 1999) found that majority of respondents generally liked their advertising and that most of those respondents liked it because they felt it was informative. Usually, the quality of that information or message placed on a company's website shows a direct influence on the customers' perceptions of the company and the company's products. It reflects how a company are associated only to find mutual understanding through message available on the web site. At the same time, information delivered to them via online media also needs to show qualitative features, such as accuracy, timeliness, and usefulness for the consumer (Siau \& Shen, 2003).

Given above we can conclude that the use of web advertising is able to give a more detailed info about a product or service. Moreover, according to (Calfee \& Ringold, 1994) reported that any advertisement that provides product information, leading to consumer education. They can explain to the target audience of the goals, expectation, and values regarding the organization as well let them know what offers organizations and consumers need. From that, maybe some improvement can be done to fulfill all the satisfaction for both. Hence, it can be expected that there is a strong relationship between informativeness with the influence factors of consumer's attitudes towards Honda web advertising. Therefore:

H1: There is a relationship between informativeness with the influence factors of consumer's attitudes towards Honda Web Advertising.

Entertainment and Consumer's Attitudes Towards Honda Web Advertisement

In this study, entertainment value is related to Hedonic/pleasure that indicates that ads can be entertaining, sentimental, expressive, and exciting (Ling et al., 2010). In addition, feelings of people about enjoyment of ads play a significant and important role in forming their general attitudes toward ads (Raza, Hasnain, et al., 2018). This includes

Jurnal The Messenger, Vol. 11, No. 1A, Special Issue on the School of Multimedia Technology and Communication Postgraduate Symposium, pp. 81-93 
feel-good, enjoyable and social image (Aziz \& Ariffin, 2010). Using well-known people such as an artist which indirectly able to bring products or services to a consumer. It is also able to attract the consumer to know about the products or services with more details and make it become more interesting while browsing the website. When we surf the Internet, it could also give a sense of satisfaction and enjoyable especially when the advertiser using our very own favourite artists as a social image on the website. In fact, entertainment denotes its full ability to fulfil individuals needs for escapism, diversion, appealing enjoyment or emotional proclamation (McQuail, 1983; Saadeghvaziri \& Seyedjavadain, 2011)

Entertainment is required for everyone which allows people to forget about the real problems of life for a while by looking for something can release their tension or stress. At the same time, entertainment can increase customer loyalty and add value to the product and organization. In this case, as most of the people have a natural playfulness, providing games and prizes via internet involved high participation. By delivering games and prizes to the customer's through internet ads is a successful way to attract and keep customers. For example, the latest contest conducted by Honda Malaysia is by viewing the Honda website, you're invited to join The Honda Road trip and served with a performance from a few of local artists, strike a pose with Honda to receive a free 16GB pendrive, Boots Sales and many more. We can see here, Honda is always trying to attract the attention of the consumers by providing something fun and interesting. Therefore, it can be hypothesized:

$\mathrm{H} 2$ : There is a relationship between the entertainment values with the influence factors of consumer's attitudes towards Honda Web Advertisement.

Credibility and Consumer's Attitudes Towards Honda Web Advertisement

Meanwhile, credibility can be defined as a believability of the address and its perception in the listener's mind (Adler \& Rodman, 2000) (Mackenzie \& Lutz, 1989) also identify advertising credibility as consumers' general perception towards the truthfulness, reliability, trustworthiness, and believability of an advertisement whether product or services. The credibility of advertising is not limited to traditional advertising, even with the advent of more advanced technology, it is necessary to focus mainly on advertising via the website or new media. In brief, credibility is about the quality of being believed or accepted as true, real, or honest. In line with the believability, trustworthy is also an important aspect in one's attitude toward web advertising. According to ( $\mathrm{Li} \&$ Zhang, 2002), the level of trust, interpersonal as well as institutional, is obviously related to consumers' attitude and their intention to shop on the Internet.

Nowadays, violation of consumers trusts in online shopping, in terms of privacy invasion or misuse of personal information, negatively influences attitude toward online shopping and leads to reluctant behavior among consumers to shop on the Internet whether via the website or new media in future occasions. If there is no believe on the information given by the advertisement then there will be no trust by a person on the advertisement (Saeed et al., 2013). Therefore, brand awareness is very important in ensuring trust in any products or services towards consumers. Thus, honesty is the best policy. Be authentic and genuine in business or dealing with consumers because it is what all of us are looking for. In this context, we can see a there is a connection between the credibility of the Honda product. Therefore, the next hypothesis could be:

H3: There is a relationship between the credibility with the influence factors of consumer's attitudes towards Honda Web Advertising. 
Economic Value and Consumer's Attitudes Towards Honda Web Advertisement

A part of it, good for the economy is also one of the influence factors of attitude towards web advertising. (Pollay \& Mittal, 1993) indicates that our ads should increase living standards, resulting in full employment, intense competition among companies and declining average product cost. This clearly shows that the economy value is more to the win-win situation between advertiser and consumer. Besides that, good for the economy is also associated with necessary to support web, other users (buying and selling), improves the standard of living and reassure using the right product (Aziz \& Ariffin, 2010). Web advertising enables consumers to save their time, purchase without hassle, have many choices, and increase the acceptance of new services and products (Korgaonkar \& Wolin, 2002; Pollay \& Mittal, 1993).

Here, we can see the prices of each car produced by Honda proportionate to with its quality and advanced technology are able to assure comfortability to users. However, not everyone can afford to have it. Thus, the concept of good for economy or economy value reflects the point of view that advertising speeds up the adoption of new goods and technologies by consumers, fosters full employment, reduces the average costs of production, elevates producers about healthy competition, and increases the standard of living on average (Belch \& Belch, 2007). Therefore:

H4: There is a relationship between economy values with the influence factors of consumer's attitudes towards Honda Web Advertising.

Interactivity and Consumer's Attitudes Towards Honda Web Advertisement

According to Zhang and Wang, 2005, interactivity is measured by two-way communication (or vividness), control, frequency of exchange, and customization. It clearly related to the virtual interactivity of interpersonal communication where people can interact each other especially through social dialogue box or any social media that linked to the website to get to know about the product. Through interactivity, it indirectly facilitates the consumer to make a choice without the need to go to the company to make a choice.

At the same time, Cho and Leckenby (1999) found that the user's intention to interact with a site and the actual number of interactive features at a site were both positively related to attitude toward the site. For example, through the website of Honda Malaysia, was declared complete specification, performance, and price of each car model and a new update (Honda, 2014). This can be seen on the Honda websites where the use of an appropriate layout, videos and websites that linked to social media such as Facebook. Therefore, it can be hypothesized.

H5: There is a relationship between the interactivity with the influence factors of consumer's attitudes towards Honda Web Advertising.

Materialism and Consumer's Attitudes Towards Honda Web Advertisement

The general meaning of materialism which can be included in the context of web advertising is to influence buy unaffordable, spending in product improvement better than web ad, dissatisfaction increases for those who cannot afford and create a materialistic society (Aziz \& Ariffin, 2010). Materialism is also seen as one of the negative attitudes because the level of desire to have something that cannot afford to buy which may lead to financial problems. Materialism is a set of belief structures that sees consumption as the route to most, if not all, satisfaction (Gao, Zhang, \& Li, 2014).

The situation will get worse if left unchecked and eventually become a part of a materialistic society in buying and owning things. In fact, Korgaonkar, Silverblatt and O'Leary (2001) also considered that web advertising makes people buy unaffordable

Jurnal The Messenger, Vol. 11, No. 1A, Special Issue on the School of Multimedia Technology and Communication Postgraduate Symposium, pp. 81-93 
products just to show off. For example, a people that have a desire to buy one of Honda car since Honda is one of the established automotive brands and looks exclusive and not everyone can afford to have it. However, it depends on the intention of the person in possession of Honda cars. Therefore, it can be hypothesized:

H6: There is a relationship between materialism with the influence factors of consumer's attitudes towards Honda web advertising.

\section{Methodology}

An online survey of the 384 respondents has been carried out to evaluate the influence of the six variables on the attitudes towards Honda's web advertisement. Krejcie and Morgan (1970) method was used as a reference for determining the sample size for a given population for this study. A total of 384 samples have been used based on the population likers on Honda Official Facebook with total more than 1000,000 likers. Distribution of this online questionnaire has also been done at random, especially for those who once have a product of Honda and those ever-viewing Honda's web advertisement. Details of the demographic profile are accessible in Table 1.

Measurements

The attitude has been measured by using the 12-items scales adopted from Korgaonkar and Wolin (2002) and Wang and Sun (2010). Based on testing performed, the Alpha Cronbach items attitudes showed excellent levels. The level of validity and reliability was $\alpha=0937$. Informativeness has been measured by using the 10 -items scales adopted from Ling et al. (2010). The Cronbach alpha for the reliability of the informativeness items is $\alpha=0.935$. Entertainment has been measured by using the eight-items scales adopted from Carlson and O'Cass (2010). The Cronbach alpha for the reliability of the entertainment items is $\alpha=0.963$. While credibility has been measured by using the three-items scales adopted from Ling et al. (2010). The Cronbach alpha for the reliability of the credibility items is $\alpha=0.914$. The economic value has been measured by using the three-items scales adopted from Aziz \& Ariffin (2010)The Cronbach alpha for the reliability of the economic value items is $\alpha=0.872$. The interactivity has been measured by using the five-items scales adopted from McMillan, Hwang, and Lee (2003). The Cronbach alpha for the reliability of the interactivity items is $\alpha=0.905$. The materialism has been measured by using the four-items scales adopted from Wolin (2002). The Cronbach alpha for the reliability of the materialism items is $\alpha$ $=0.913$.

Table 1. Demographic Profile

\begin{tabular}{ccc}
\hline Demographic & Frequency & Percentage \\
\hline Gender & 221 & 57.6 \\
Male & 163 & 42.4 \\
Female & Frequency & Percentage \\
\hline Age & 177 & 46.1 \\
$18-24$ & 156 & 40.6 \\
$25-34$ & 20 & 5.2 \\
$35-44$ & 25 & 6.5 \\
$45-54$ & 6 & 1.6 \\
$55-64$ & Frequency & Percentage \\
\hline Race & 285 & 13.0 \\
\hline Malay & 50 & \\
Chinese & &
\end{tabular}




\begin{tabular}{ccc} 
Indian & 45 & 11.7 \\
Others & 4 & 1.0 \\
\hline
\end{tabular}

Source: Authors Estimations

\section{Results and Discussion}

The descriptive analysis has been carried out on SPSS 20 to analyze the data normality and revealed that all seven variables were normally distributed. The Table 2 , shows the descriptive statistics of all seven variables. Further correlation analysis determined the relationship between attitudes and six independent variables was significant and positive.

Table 2. Descriptive and Correlation Analysis

\begin{tabular}{ccccccccc}
\hline Variable & Mean & ATWA & IF & EN & CB & EV & IN & MT \\
\hline ATWA & 3.50 & 1 & & & & & & \\
IF & 3.82 & $.81^{*}$ & 1 & & & & & \\
EN & 3.69 & $.85^{*}$ & $.55^{*}$ & 1 & & & & \\
CB & 3.56 & $.79 *$ & $.34^{*}$ & $.27^{*}$ & 1 & & & \\
EV & 3.39 & $.67^{*}$ & $.18^{*}$ & $.23^{*}$ & $.43^{*}$ & 1 & & \\
IN & 3.58 & $.80^{*}$ & $.64^{*}$ & $.12^{*}$ & $.23^{*}$ & $.43^{*}$ & 1 & \\
MT & 3.60 & $.35^{*}$ & $.41^{*}$ & $.22^{*}$ & $.56^{*}$ & $.63^{*}$ & $.17 *$ & 1 \\
\hline Source: & Authors & Estimations, & ATWA: & Attitude & Towards & Honda & Ads, IF $=$
\end{tabular}
Informativeness; $\mathrm{EN}=$ Entertainment; $\mathrm{CB}=$ Credibility; $\mathrm{EV}=$ Economic Value; $\mathrm{IN}=$ Interactivity; $\mathrm{MT}=$ Materialism; and $*=\mathrm{P}$ significant Hypothesis Testing

Meanwhile, the multiple regression has been employed to test the influence of the six independent variables, Informativeness (IF), Entertainment (EN), Credibility (CB), Economic Value (EV), Interactivity (IN) and Materialism (MT) on attitude towards Honda ads (ATWA). The results demonstrated that the six-independent variables have a significant influence on the attitude towards Honda ads (ATWA) with the overall $\mathrm{R}^{2}$ value is 0.73 which means $73 \%$ of the cases predict the dependent variable (ATWA). The result of regression anlysis suggested that the all six hypotheses were supported. Among the influential factors informativeness (IF) remains the most significant factor in predicting the ATWA. The results in Table 3 shows that the direct relationship of (IF) and ATWA is strongest among all other factors $(\beta=.42, \mathrm{p}=.01)$ and H1 is accepted.

Table 3. Multiple Regression with Community Involvement (CI) as Dependent Variable

\begin{tabular}{cccccc}
\hline Variable & $\beta$ & S.E & t-stat. & p-value & Hypothesis \\
\hline IF & .42 & .041 & 3.45 & .011 & H1 supported \\
EN & .23 & .021 & 5.64 & .000 & H2 supported \\
CB & .19 & .017 & 3.21 & .023 & H3 supported \\
EV & .27 & .023 & 4.89 & .000 & H4 supported \\
IN & .38 & .043 & 6.78 & .017 & H5 supported \\
MT & .13 & .036 & 4.12 & .000 & H6 supported \\
Adj. R & .73 & & & & \\
F (8,345) & 105.34 & & & & \\
DW & 2.341 & & & & \\
N & 384 & & & & \\
\hline
\end{tabular}

Source: Authors Estimations, Dependent Variable: Attitude Towards Honda Ads; Adj. $\mathrm{R}^{2}=$ Adjusted $\mathrm{R}$ squared; $\mathrm{F}=$ Analysis of variance; $\mathrm{DW}=$ Durbin Watson statistics; and $\mathrm{N}=$ Sample.

Jurnal The Messenger, Vol. 11, No. 1A, Special Issue on the School of Multimedia Technology and Communication Postgraduate Symposium, pp. 81-93 
The direct influence of (EN) on ATWA also revealed significantly positive ( $\beta$ $=.23, \mathrm{p}=.00)$ and $\mathrm{H} 2$ is accepted. The direct influence of $(\mathrm{CB})$ on ATWA also revealed significantly positive $(\beta=.19, \mathrm{p}=.02)$ and $\mathrm{H} 3$ is accepted. The direct influence of (EV) on ATWA also revealed significantly positive $(\beta=.27, \mathrm{p}=.00)$ and $\mathrm{H} 4$ is accepted. The direct influence of (IN) on ATWA also revealed significantly positive $(\beta=.38, p=.02)$ and H5 is accepted. The direct influence of (MT) on ATWA also revealed significantly positive ( $\beta=.13, \mathrm{p}=.00)$ and H6 is accepted, however, (MT) remained as the weakest predictor among all predictors.

Based on the data analysis and result, it turns out there is a positive relationship between the antecedent of the focal construct. The studies also proved that informativeness greatly affects attitudes of consumers towards Honda's web advertisement. It supports past research that it reflects how a company is associated only to find mutual understanding through message available on the website. At the same time, information delivered to them via online media also needs to show qualitative features, such as accuracy, timeliness, and usefulness for the consumer (Siau \& Shen, 2003). Therefore, good product information supposedly helps online shoppers or any website viewer to make better decisions, feel more confident about their decisions, and at the same time increase satisfaction with the shopping experience and improve attitude towards a website.

Meanwhile, through correlation, the lowest mean score is on the materialism section with the total mean score is 3.00 . Based on the results obtained, item by viewing Honda's web advertisement or by having any product of Honda making us materialistic society showed the mean score is 20.03 while the item by viewing Honda's web advertisement or having any product of Honda makes people just to show off have the lowest mean score with a total of 2.82 only. However, according to Eze and Lee (2012) agreed that majority of the respondents feel that advertising makes people live in a world of fantasy and it results into a materialistic society, which is overly interested in buying and owning possessions. In fact, in this 21 st century, advertising tends to increase the hunger in our materialistic society by promoting products that they yearn to own as a label of power and some of them just to show off.

\section{Conclusion}

Based on the model Elaboration Likelihood Model (ELM), which was introduced by Petty and Cacioppo (1986) it is indirectly linked to this study. Generally, ELM has 2 routes for persuasion, involving central and peripheral routes. It involves attitudes and motivates them towards the stimulus. For example, these two routes have been applied by the viewer of Honda's web advertisement according to the needs of each viewer. Basically, the central route is utmost properly used when the receiver is inspired to contemplate the message and can contemplate about the message or certain information. Long-lasting persuasion is expected if the receiver contemplates, or reviews, favorable judgments about the message cement that involves cognitive and for a long-term change in attitude and involved the decision-making process.

Contrary with the peripheral route, it involves communication strategies advocated by trying to assemble the position with the receiver existing thoughts, for example, towards food or money using an expert appeal and so on. Here, when they are feeling upright, they probably sustain viewing Honda's website and will avoid focusing on things that might bring them down again, so they take a more cursory and that's what it called peripheral route. In this study, the attitudes are more inclined towards the 
central routes is informativeness, credibility and economic value. Through information or message that has been providing thorough Honda's website, it clearly shows that viewer has an ability to engage in issue-relevant thinking. Besides that, because of their trustworthy and believe towards all the content of the information on Honda's website, they are able to elaborate the information. In line with that, they are able to engage with the economic value where some of them believe that people wear branded good because of the Honda's web advertisement.

Next, peripheral routes that involved in this study involved three main aspects which is entertainment, interactivity, and materialism. This can be seen through the website of Honda that has innovative features, creative and looks good. It is the way to attract or to persuade viewers to maintain Honda's website viewing. In addition, through interactivity aspect, visuals of Honda products sound, feel, look real and keeps viewer attention. Lastly, materialism aspect makes them have any product of Honda making us interested and materialistic society-time makes some other people just to show off by viewing or having any product of Honda. All of this usually 'automatic, shallow, heuristic, and mindless and based on effective associations or simple inferences tied to peripheral cues' (Petty \& Cacioppo, 1986). Thus, this study clearly shows that ELM interrelated with the influence factors of consumer's Attitudes Towards Web Advertising (ATWA) on Honda web advertisement.

Managerial Implications

Overall, the findings of this study are relatively promising and emphasize the influence factors of consumer's attitudes towards advertising web on Honda web advertisement. This research established that all the independent variables, which involved informativeness, entertainment, credibility, economic value, interactivity, and materialism are among the influence factors of consumer's attitudes towards Honda's web advertisement. At the same time, this proves informativeness factors play an important role in attracting viewers to browse Malaysia Honda website. It also shows that Honda's web advertisement assists them in finding adequate information regarding the product that they want. This includes terms of price, specification, design and so on.

In addition, majority viewer of Honda's Malaysia website so interested in the entertainment aspect is there in terms of the Honda website visualization, creativity and innovative concept that are applied in Honda's website. This adds excitement to continue towards consumers to view Honda's website and stimulate them towards purchase intention. Moreover, based on their understanding and research towards the history of Honda product, some of them believe that the product Honda is a brand that can be trusted and that which aired on Honda's website is the same as in reality. It directly can create brand loyalty among consumers. In terms of economic value, although only several of them feel that using any product of Honda's website or by viewing can improve their lives, most of them believe that people wear branded goods because of Honda's advertisement.

Other than that, in accordance with the passage of time, advertising on the website have also changed. The changes also apply to Honda's web advertisement. With an attractive interface and sounds and looks like a real model or 3D can stimulate their interest to keep viewing the Honda website. In addition, Honda's web advertisement load fast and make people less annoyed. Besides that, some of them agree that some of them buy unaffordable products just to show off. This can create materialistic society interested, making in buying and owning things. In brief, there are many factors that can influence the consumer's attitudes towards advertising web on Honda web

Jurnal The Messenger, Vol. 11, No. 1A, Special Issue on the School of Multimedia Technology and Communication Postgraduate Symposium, pp. 81-93 
advertisement. However, it depends on each individual and what are the reasons that stimulate them to view the ads or what excites them. Therefore, this study was providing a new pathway in ATWA especially towards Honda's Web Advertisement.

Limitations and Future Research

One of the obvious drawbacks of this study is the sample which has collected too wide, regardless of demographic background. This limitation can cause target respondent cannot be achieved effectively by collecting data just using Google online form and no approach and extensive exposure to the respondents to this survey. This is because not all the official Honda Facebook likers have ever viewed the Honda's website or possess any product of Honda. Perhaps some of them only recognize the product of Honda in name only. Moreover, distribute the questionnaire via email is also time-consuming because not all of them will reply on the spot. This will run the risk of response bias. This can be seen through collecting data when respondents might respond to what they think the researcher is looking for rather than what is their actual thinking, feeling and their experience. Future studies can use the mixed method research as it can indirectly cover quantitative and qualitative research in which a combination of both methods can produce a result that is more convincing and comprehensive.

\section{Acknowledgements}

The authors would like to thank all experts and respondents, especially 384 Honda users who were respondents to the study.

\section{References}

Adler, R. B., \& Rodman, G. (2000). Understanding human communication. Ft Worth: Harcourt College Publishers.

Andersen, S., \& Zaelke, D. (2003). Industry Genius: Inventions and People Protecting the Climate and Fragile Ozone Layer. Sheffield: Greenleaf Publishing.

Aziz, N. A., \& Ariffin, A. A. M. (2010). Exploring Consumers Attitude towards Web Advertising and its Influence on Web Ads Usage in Malaysia. Jurnal Pengurusan, $31,55-63$.

Belch, G., \& Belch, M. (2007). Advertising and promotion: An integrated marketing.

Bleier, A., \& Eisenbeiss, M. (2015). Personalized online advertising effectiveness: The interplay of what, when, and where. Marketing Science, 34(5), 669-688.

Boudreau, M., \& Watson, R. (2006). Internet Advertising Strategy Alignment. Internet Research, 16, 23-37.

Calfee, J., \& Ringold, D. (1994). The 70\% majority: enduring consumer beliefs about advertising. Journal of Public Policy \& Marketing, 13, 228-238.

Carlson, J., \& O'Cass, A. (2010). Exploring the relationships between e-service quality, satisfaction, attitudes and behaviours in content-driven e-service web sites. Journal of Services Marketing, 24(2), 112-127.

Cho, C. H., \& Leckenby, J. D. (1999). Interactivity as a measure of advertising effectiveness: Antecedents and consequences of interactivity in web advertising. Proceedings of the 1999 Conference of the American Academy of Advertising, 162-179.

Eze, U. C., \& Lee, C. H. (2012). Consumers' Attitude towards Advertising. International Journal of Business and Management, 7(13), 94-108. https://doi.org/10.5539/ijbm.v7n13p94

Gao, Z., Zhang, H., \& Li, S. F. (2014). Consumer Attitudes Toward Advertising in the 
Digital Age: A China-United States Comparative Study. Journal of Current Issues \& Research in Advertising, 35(1), 12-28.

Goldsmith, R., \& Lafferty, B. (2002). Consumer response to Web sites and their influence on advertising effectiveness. Internet Research, 12(4), 318-328.

Ham, C. D. (2017). Exploring how consumers cope with online behavioral advertising. International Journal of Advertising, 36(4), 632-658.

Honda. (2014). The Official Home of Honda Malaysia. Retrieved from http://www.honda.com.my

Jung, J., Shim, S. W., Jin, H. S., \& Khang, H. (2016). Factors affecting attitudes and behavioural intention towards social networking advertising: a case of Facebook users in South Korea. International Journal of Advertising, 35(2), 248-265.

Kerr, G., Schultz, D. E., Kitchen, P. J., Mulhern, F. J., \& Beede, P. (2015). Does Traditional Advertising Theory Apply to the Digital World?: A Replication Analysis Questions the Relevance Of the Elaboration Likelihood Model. Journal of Advertising Research, 55(4), 390-400.

Korgaonkar, P., Silverblatt, R., \& O'Leary, B. (2001). Web advertising and Hispanics. Journal of Consumer Marketing, 18(2), 134-152.

Korgaonkar, P., \& Wolin, L. (2002). Web usage, advertising, and shopping: relationship patterns. Internet Research, 12(2), 191-204.

Krejcie, R. ., \& Morgan, D. . (1970). Determining Sample Size for Research Activities. Determining Sample Size for Research Activities.

Li, N., \& Zhang, P. (2002). Consumer Online Shopping Attitudes and Behavior: An Assessment of Research. Eighth Americas Conference on Information Systems, 508-514.

Ling, K. C., Piew, T. H., \& Chai, L. T. (2010). The determinants of consumers' attitude towards advertising. Canadian Social Science, 6(4), 114-126.

Lutz, R. J. (1985). Affective and Cognitive Antecedents of Attitude toward the Ad: A conceptual framework, In Psychological Processes and Advertising Effects. Theory, Research and Application, Eds., 45-46.

Mackenzie, S. ., \& Lutz, R. . (1989). An empirical examination of the structural antecedents of attitude toward the ad in an advertising pre testing context. Journal of Marketing, 53(April), 48-65.

McMillan, S., Hwang, J., \& Lee, G. (2003). Effects of structural and perceptual factors on attitudes toward the website. Journal of Advertiisng Research, 43(4), 400-409.

McQuail, D. (1983). Mass Communication Theory: An Introduction. London: Sage Publications Inc.

Petty, R. ., \& Cacioppo, J. . (1986). The elaboration likelihood model of persuasion. In Communication and persuasion. New York: Springer.

Petty, R. E., Briñol, P., \& Tormala, Z. L. (2002). Thought confidence as a determinant of persuasion: The self-validation hypothesis. Journal of Personality and Social Psychology, 82(5), 722-741.

Pollay, R. ., \& Mittal, B. (1993). Here's the beef: factors, determinants, and segments in consumer criticism of advertising. Journal of Marketing, 57(3), 99-114.

Raza, S. H., Bakar, H. A., \& Mohamad, B. (2018). Advertising appeals and Malaysian culture norms. Journal of Asian Pacific Communication, 28(1), 61-82.

Raza, S. H., Hasnain, A., \& Khan, S. W. (2018). Cross-Cultural Evaluation of the Mediation of Attitudes in Relationship of Cultural Values and Behavioral Reactions toward Web Based Advertising. South Asian Journal of Management

Jurnal The Messenger, Vol. 11, No. 1A, Special Issue on the School of Multimedia Technology and Communication Postgraduate Symposium, pp. 81-93 
Sciences, 12(1), 1-24.

Saadeghvaziri, F., \& Seyedjavadain, S. (2011). Attitude toward advertising: mobile advertising vs. advertising-in-general. European Journal of Economics, Finance and Administrative Sciences, 28(28), 104-114.

Saeed, R., Lodhi, R., Naeem, A., Akbar, A., Sami, A., \& Dustgeer, F. (2013). Consumer's Attitude towards Internet Advertising in Pakistan. World Applied Sciences Journal, 25(4), 623-628.

Schlosser, A., Shavitt, S., \& Kanfer, A. (1999). Survey of Internet User's Attitude toward Internet Advertising. Journal of Interactive Advertising, 13(3), 1-21.

Siau, K., \& Shen, Z. (2003). Building customer trusts in e-mail commerce. Communications of the ACM, 46(4), 91-94.

Stephen, A. T. (2016). The role of digital and social media marketing in consumer behavior. Current Opinion in Psychology, 10, 17-21.

Wang, Y., \& Sun, S. (2010). Examining the role of beliefs and attitudes in online advertising: a comparison between the USA and Romania. International Marketing Review, 27(1), 87-106.

Yang, Z., Peterson, R. ., \& Huang, L. (2001). Taking the pulse of internet pharmacies. Marketing Health Services, 21(2), 4-10.

Zhang, P., \& Wang, C. (2005). An Empirical Study on Consumer's Perceived Value and Attitude towards Advertising. Proceedings of the 6Th Global Information Technology and Management (GITM) World Conference. 